\title{
In vitro Investigation of the Anti-sickling and Erythrocyte Membrane Stabilizing Potentials of Elaesis guineensis Jacq Flower
}

\author{
Florence Ezewanyi Ogwutum, Augustine Amadikwa Uwakwe, Mathew Owhonda Wegwu, \\ Justice Obinna Osuoha*
}

Department of Biochemistry, University of Port Harcourt, Nigeria

Copyright $\mathrm{O} 2018$ by authors, all rights reserved. Authors agree that this article remains permanently open access under the terms of the Creative Commons Attribution License 4.0 International License

\begin{abstract}
Anti-sickling activity of Elaeis guineensis jacq flowers was investigated to determine the capability of the plant to inhibit the polymerization of sickle cell hemoglobin, maintain membrane osmotic fragility and recover the $\mathrm{Fe}^{2+} / \mathrm{Fe}^{3+}$ ratio. Spectrophotometric technique was employed to determine the rate of sodium metabisulphite provoked HbSS erythrocytes polymerization. The profile for HbSS erythrocytes polymerization of test and control specimens demonstrated growing level of polymerization at three investigational concentrations $(20 \mathrm{mg} / \mathrm{ml}, 40 \mathrm{mg} / \mathrm{ml}$ and $60 \mathrm{mg} / \mathrm{ml})$ while $(80 \mathrm{mg} / \mathrm{ml}, 100 \mathrm{mg} / \mathrm{ml}, 120 \mathrm{mg} / \mathrm{ml})$ concentrations of the extracts showed pronounced anti-sickling activity through inhibition of HbSS gelation. The estimation of mean corpuscular fragility (MCF), which is the concentration of saline causing $50 \%$ hemolysis of the erythrocytes, revealed that the plant extract decreased the MCF values of the HbSS erythrocytes at all concentrations in comparison to the control. The $\mathrm{Fe}^{2+} / \mathrm{Fe}^{3+}$ investigation revealed an increase in the test groups when compared to the control. The aqueous extracts of Elaeis guineensis jacq flowers demonstrated towering potency in altering the polymerization of sickle cell hemoglobin at increased concentration, enhancement in $\mathrm{Fe}^{2+} / \mathrm{Fe}^{3+}$ ratio and maintaining erythrocyte membrane integrity.
\end{abstract}

Keywords Sickle Cell Hemoglobin, Polymerization, Osmotic Fragility, Sodium Metabisulphite, Elaeis guineensis Flowers

\section{Introduction}

Drepanocytosis, a genetic disorder of the blood commonly called sickle cell disease is associated with formation of abnormal crescent or sickle shape by the erythrocytes and characterized with recurrent painful episodes and life-long anemia. It occurs technically as a result of mutation (point mutation) interfering with the coding series of nucleotides in which a polar amino acid, glutamic acid is substituted by valine, a non polar amino acid $[1,2]$. The affinity of oxygen for hemoglobin is decreased because of this mutation, deoxyHbS molecules polymerize inside the erythrocytes under hypoxic conditions leading to red blood cells damage and membrane deformity with concomitant gel formation (reduced solubility) [3].

Inhibition or retardation of hemoglobin aggregation and polymerization is sacrosanct, the use of drugs that either interact with $\mathrm{HbS}$ molecules either covalently or non-covalently $[4,5]$, bone marrow transplant $[6,7]$, stimulation of fetal hemoglobin appearance $[2,8]$ to inhibit hemoglobin polymerization has been demonstrated as some of the therapeutic advances for the treatment and control of sickle cell anemia. Furthermore, several researchers $[9,10,11,12]$ had reported the application of herbal formulations for the control of the disease and hence the proponent for this study. In the fervent search for antisickling agents, apparently the role of nutrition is revolutionary in the management and possible prevention of the disease. Bulson et al. [13] reported that patients suffering from sickle cell disease lack some nutrients and amino acids, vitamin D and C, and Zinc etc. were among the nutrients implicated in the patients suffering from this disease hence for reduction of some pathological conditions of this ailment and perhaps improvement on the projection of its syndrome nutritional supplementation is also sacrosanct. These nutrients help to improve the oxygen attraction of the red blood cell thereby inhibiting the aggregation of the hemoglobin of sickle cell individuals.

In developing countries like Nigeria, where satisfactory health care is grossly missing and incomes are relatively 
low, most citizens who suffer from this disease can't afford the drugs used in managing the disease, so the hunt for cost effective drugs, herbal formulations and nutrients to control and treat the syndrome obliged the application and trial of numerous substances available in the society.

The Oil Palm known in the scientific world as Elaeis guineensis Jacq originated from Guinea in West Africa. Different fractions of the tree are widely utilized for numerous medicinal purposes traditionally of which most of them has been confirmed by numerous clinical experiments [43]. Palm oil is extracted after series of preparation from the mesocarp of the fruit while the leaves of the tree have been alleged to be potent in the control of cardiovascular diseases, wound healing, cancer etc. The sap is very rich in some phytonutrients which is used for the management of numerous diseases. Much research had not been made on the flower which is overly overlooked by citizens and researchers. According to Chikezie [11] polymerization of $\mathrm{HbS}$ molecules has been inhibited by various plant extracts in vitro.

Therefore, this current investigation desires to establish the in vitro capability of aqueous extract of Elaeis guineensis Jacq flowers to interfere with the aggregation of HbSS molecules, maintain erythrocyte membrane integrity and determine the proximate content of the plant extract.

\section{Materials and Methods}

\subsection{Sample Collection}

Dried samples of Elaeis guineensis Jacq were obtained from University of Port Harcourt farm and was identified and authenticated at the Department of Plant Science and Biotechnology, University of Port Harcourt.

\subsection{Preparation of Elaeis Guineensis Jacq Plant Extract}

Elaeis guineensis Jacq plant extract was prepared according to the technique illustrated by Chikezie and Uwakwe [12]. Exactly twenty five grams of processed leaves of Elaeis guineensis Jacq harvested from University of Port Harcourt farm were collected in desiccators and allowed to dry for seventy two hours to become crispy. Afterwards, the dried specimen was ground in ceramic mortar and pestle into fine powder. Furthermore, the pulverized specimen was suspended in $100 \mathrm{~mL}$ of distilled water and allowed to stand for six hours at $37^{\circ} \mathrm{C}$. Aqueous extract of $E$. guineensis was obtained by filtration with Whatman No. 2 filter paper. Finally, the extract was concentrated in a rotary evaporator at $50^{\circ} \mathrm{C}$ and dried in vacuum desiccators. The extract was finally suspended in $50 \mathrm{~mL}$ phosphate buffered saline (PBS) solution osmotically equivalent to $0.9 \mathrm{~g} / 100 \mathrm{~mL} \mathrm{NaCI}$ [14]. The extract was kept at $4^{\circ} \mathrm{C}$ in a refrigerator for at least 24 hours before subsequent tests. Concentration equivalents of 20 , $40,60,80,100$ and 120 milligram per milliliter aqueous extracts of Elaeis guineensis Jacq were utilized for polymerization experiment.

\subsection{Collection and Preparation of Erythrocyte Hemolysate}

Using a venipuncture, $5 \mathrm{ml}$ of blood was drawn from three volunteers and was preserved in anticoagulant tubes (EDTA). The samples were got from volunteer patients receiving medical healthcare at the University of Port Harcourt Teaching Hospital.

The Institutional Review Board of the Department of Biochemistry, University of Port Harcourt, Nigeria, granted approval for this study and all volunteers involved signed an informed consent form. This study was in harmony with the ethical principles that have their origins in the Declaration of Helsinki.

Using the centrifugation technique illustrated by Tsakiris et al. [15] with little amendment according to Pennings et al. [16], the obtained blood samples were washed after separation from plasma. Exactly $5 \mathrm{ml}$ of the blood sample was added into the centrifuge test tube possessing $5 \mathrm{ml}$ of the buffer solution and centrifuged for ten minutes at four thousand rpm. Using a Pasteur pipette, the supernatant and plasma were removed and this procedure was done repeatedly until the supernatant was clear. In order to obtain $10 \%$ hematocrit, the samples were suspended at a $\mathrm{pH}$ of 7.4 in a PBS solution and preserved for twenty hours at four degree centigrade. As illustrated by Galbraith and Watts [17] and Kamber et al. [18] the erythrocytes after washing were lysed by freezing. Furthermore, the lysed erythrocyte hemosylate was utilized for the polymerization experiments.

\subsection{Polymerization Experiments}

Sodium meta-bisulfite induced polymerization of molecules of $\mathrm{HbS}$ was determined as illustrated by Iwu et al. [19] with little amendment according to Chikezie et al. [20].

\section{Principle}

When deprived of oxygen, molecules of HbS experience gelation, transforming to deoxyHbS molecules.

\section{Procedure}

Exactly $0.1 \mathrm{ml}$ of $\mathrm{HbS}$ hemolysate was added into a test tube and then $0.5 \mathrm{ml}$ of PBS and $1 \mathrm{ml}$ of distilled water was introduced afterwards. The mixture was reassigned into a beaker and $3.4 \mathrm{ml}$ of $2 \mathrm{~g} / \mathrm{ml}$ aqueous solution of sodium meta-bisulfite was introduced. Using a spectrophotometer, the absorbance of the mixture was recorded at every thirty seconds for one hundred and eighty seconds (control test). This procedure was repeated by replacing distilled water 
with one point zero milliliter of six increasing concentrations $(20,40,60,80,100$ and 120 milligram per milliliter) of E. guineensis extracts (test specimen) respectively. Sodium meta-bisulfite was utilized specifically as a reductant. The intensity of polymerization was deduced by documenting changes in absorbance of the test mixture with succession of time.

\section{Calculations}

Percentage polymerization was determined mathematically as proposed by Chikezie et al. [20] thus;

$$
\% \text { Polymerization }=\frac{\text { At } / \mathrm{c}}{\text { Ac180thsec }} \times \frac{100}{1}
$$

Where

$\mathrm{At} / \mathrm{c}=\mathrm{Absorbance}$ of test/control assay at time $=\mathrm{t}(\mathrm{s})$.

Ac180 ${ }^{\text {th }}$ secs $=$ Absorbance of control assay at the $180^{\text {th }} \mathrm{s}$.

\subsection{Erythrocyte Osmotic Fragility Tests}

The erythrocyte osmotic fragility test was performed based on the technique illustrated by Dewey et al. [21] with minor amendment as documented by Chikezie [11]. The fraction of erythrocytes lysed when suspended in saline solution of varying concentrations was investigated by spectrophotometric method.

\subsection{Evaluation of Percentage Hemolysis and Stabilization of Erythrocytes}

The measure of absorbance of the test tubes (1-6) were obtained and multiplied by 100 . The values stand for the percentage of erythrocyte lysis at each saline concentration. The mean corpuscular fragility (MCF) index was the corresponding concentration of saline solution $(\mathrm{NaCl} \mathrm{g} / \mathrm{L})$ that caused $50 \%$ lysis of erythrocytes [21]. The MCF values were obtained from the cumulative erythrocyte osmotic fragility curves obtained by plotting the percentage lysis against saline concentrations.

The capability of the aqueous extract of E. guineensis flower to disrupt or stabilize erythrocyte membrane was estimated as percentage of the quotient of the difference between the MCF values of the test and control sample to the control sample [12].

Thus

$$
\% \text { Stability }=\frac{(\text { MCF control }- \text { MCF test }) \times 100}{\text { MCF control }}
$$

\subsection{Determination of $\mathrm{Fe}^{2+} / \mathrm{Fe}^{3+}$ Ratio}

The $\mathrm{Fe}^{2+} / \mathrm{Fe}^{3+}$ ratio was determined by the methods of Davidson and Henry, [22]. The oxygen affinity of hemoglobin and methemoglobin were measured at 540 $\mathrm{nm}$ and $630 \mathrm{~nm}$ respectively. The approach employs lyzing $0.02 \mathrm{ml}$ whole blood in $5.0 \mathrm{ml}$ distilled water and $0.02 \mathrm{ml}$ normal control. To determine the $\mathrm{Fe}^{2+} / \mathrm{Fe}^{3+}$ ratio, $0.02 \mathrm{ml}$ of the anti-sickling agent was added to $5.0 \mathrm{ml}$ distilled water and $0.02 \mathrm{ml}$ of blood and incubated for $1 \mathrm{hr}$ in a test tube. The absorbances of $\mathrm{Hb}$ and metHb were measured according to the method above.

\subsection{Statistical Analysis}

SPSS Software 20 (Chicago, IL, USA) was used for statistical analysis of obtained triplicate data. Mean values \pm SD were calculated and One-Way ANOVA test was performed. Significance level was calculated at $95 \%$ confidence level $(P<0.05)$ as reported by Nwaichi et al. [44].

\section{Results}

The data in (Table 1) revealed that the plant extract decreased the MCF values of the HbSS erythrocytes at all concentrations when compared to the control. Which suggest that aqueous extract of E. guineensis flower possess strong anti-sickling potential while the results in (Table 2) showed the first three concentrations $(20 \mathrm{mg} / \mathrm{ml}$, $40 \mathrm{mg} / \mathrm{ml}$ and $60 \mathrm{mg} / \mathrm{ml}$ ) of the plant extracts increased the polymerization of the erythrocyte while the other concentrations $(80 \mathrm{mg} / \mathrm{ml}, 100 \mathrm{mg} / \mathrm{ml}, 120 \mathrm{mg} / \mathrm{ml})$ of the extracts showed pronounced anti-sickling activity through inhibition of $\mathrm{HbSS}$ gelation. The data in (Table 3) uncovered how the plant extract improved $\mathrm{Fe}^{2+} / \mathrm{Fe}^{3+}$ ratio of sickle cell blood.

Table 1. Human sickle erythrocytes mean corpuscular fragility and stability (\%) in the presence of Elaeis guineensis Jacq

\begin{tabular}{|c|c|c|}
\hline Concentration $(\mathrm{mg} / \mathrm{ml})$ & MCF & Stability \\
\hline 0 & $6.50 \pm 0.00^{\mathrm{g}}$ & 0.00 \\
\hline 20 & $4.35 \pm 0.02^{\mathrm{f}}$ & $32.95^{\mathrm{S}}$ \\
\hline 40 & $4.50 \pm 0 / 03^{\mathrm{e}}$ & $29.99^{\mathrm{S}}$ \\
\hline 60 & $4.45 \pm 0.05^{\mathrm{d}}$ & $31.53^{\mathrm{S}}$ \\
\hline 80 & $4.75 \pm 0.02^{\mathrm{c}}$ & $26.87^{\mathrm{S}}$ \\
\hline 100 & $4.85 \pm 0 / 01^{\mathrm{b}}$ & $25.39^{\mathrm{S}}$ \\
\hline 120 & $4.98 \pm 0.11^{\mathrm{a}}$ & $24.12^{\mathrm{S}}$ \\
\hline
\end{tabular}

MCF values are means \pm standard deviation of triplicate determinations. Values down the column with different superscripts are significantly different when compared to the control group.

$\mathrm{S}$ : percentage of membrane stabilization

Table 2. Percentage hemolysis of human sickle erythrocytes incubated in aqueous extracts of Elaeis guineensis Jacq

\begin{tabular}{|c|c|c|}
\hline Concentration $(\mathrm{mg} / \mathrm{ml})$ & $\Delta$ optical density/min & \% Polymerization \\
\hline Control & 0.48 & 100 \\
\hline 20 & 0.64 & 133 \\
\hline 40 & 0.60 & 125 \\
\hline 60 & 0.54 & 112.5 \\
\hline 80 & 0.46 & 95 \\
\hline 100 & 0.40 & 83 \\
\hline 120 & 0.34 & 70 \\
\hline
\end{tabular}


Table 3. In vitro effects of Elaeis guineensis Jacq flower in the $\mathrm{Fe}^{2+} / \mathrm{Fe}^{3+}$ ratio of Sickle cell blood

\begin{tabular}{|c|c|c|}
\hline Concentration $(\mathrm{mg} / \mathrm{ml})$ & $\% \mathrm{Hb}$ & $\mathrm{Fe}^{2+} / \mathrm{Fe}^{3+}$ \\
\hline HbSS (Control) & 81.81 & $4.5 \pm 0.00^{\mathrm{d}}$ \\
\hline 20 & 82.94 & $4.8 \pm 0.17^{\mathrm{d}}$ \\
\hline 40 & 82.37 & $4.6 \pm 0.53^{\mathrm{d}}$ \\
\hline 60 & 82.75 & $4.75 \pm 0.43^{\mathrm{d}}$ \\
\hline 80 & 84.16 & $5.3 \pm 0.04^{\mathrm{c}}$ \\
\hline 100 & 85.94 & $6.12 \pm 0.46^{\mathrm{b}}$ \\
\hline 120 & 86.87 & $6.89 \pm 0.02^{\mathrm{a}}$ \\
\hline
\end{tabular}

$\mathrm{Fe}^{2+} / \mathrm{Fe}^{3+}$ values are means \pm standard deviation of triplicate determinations. Values down the column with different superscripts are significantly different when compared to the control group

\section{Discussion}

Osmotic fragility of erythrocytes reflects their ability to take up water without lysis in pathological and normal states [23]. The contribution and capacity of the E. guineensis Jacq flowers extract to stabilize or alter the integrity of erythrocyte membrane is deduced and represented based on the MCF values demonstrated in (Table 1). When the levels of Means corpuscular fragility of the test assay is lower than those of the control specimen, it implies that the test assay improved the fragility of the erythrocytes according to Dewey et al. [21].

The present investigation showed the capacity of aqueous extract of $E$. guineensis to stabilize the membrane integrity of the erythrocytes, which apparently was a clear suggestion of decreased hemolysis in induced hypotonic stress state. It's not unlikely that increasing the concentration of the extracts enhanced the capacity of the erythrocytes to resist low concentrations of $\mathrm{NaCl}$ thus enhancing the stabilization effect, producing a more biconcave shape by reverting the sickled erythrocyte and hence maintaining the integrity of the erythrocyte membrane [24]. Similar observation was documented for homoserine which hinders the sickling of HbSS erythrocytes in vitro in hypotonic solutions [25]. This finding suggests the beneficial influence of the aqueous extract of E. guineensis to HbSS patients as disclosed in the increased in vitro stabilization of the $\mathrm{HbS}$ erythrocytes.

Sickle erythrocytes are predisposed to endogenous oxidative damage mediated by free radicals which is associated with the ratio of permanently sickled erythrocytes [26]. Furthermore, Tamer et al. [27] disclosed that an elevated level of free radicals in $\mathrm{HbS}$ erythrocytes is not unconnected with increased predisposition of diminished osmotic stability. Consequently, increased concentration of oxidant leads to senescence and accelerated damage to the membrane of $\mathrm{HbS}$ erythrocyte [26]. Numerous clinical trials $[27,28,29,30,31]$ have established that the activity of free radicals can be scavenged and ultimately blocked. Moreover, several authors [32, 33, 34, 35] demonstrated that flavonoids, which act as a potent free radical scavenger can inhibit membrane damage and lipid peroxidation. Although the mode and active constituents of the aqueous extract of $E$. guineensis culpable for the membrane stabilizing potentials has not been clearly elucidated and is not in the scope of this present study, various researchers time and again have implicated triterpenoids, flavonoids and a variety of plant secondary components and metabolites as the principle contributors to the membrane stabilization potentials of plant extracts [36, 37, 38]. On such premise, it is not unlikely that rutin present in the plant extract which has long been touted as a secondary flavonoid may have mediated the strong membrane stabilizing effects of the plant extract. This finding is in consonance with the report of Elekwa et al. [39] who observed the stabilization of HbSS erythrocyte membrane by Garcinia kola extract and Elekwa et al. [24] who also observed membrane stabilization by $Z$. macrophylla roots extracts.

Furthermore as demonstrated in (Table 2) HbS gelation occurred swiftly in the control assay, this swift occurrence was due to sodium metabisulphate because of its potent reducing potentials has the capacity to eliminate oxygen from the environment where the hemoglobin is inherent thus eliciting the ultimate gelation of $\mathrm{HbS}$ erythrocytes and resulting sickling of the erythrocytes.

Furthermore, the first three concentration equivalents ( $20 \mathrm{mg} / \mathrm{ml}, 40 \mathrm{mg} / \mathrm{ml}, 60 \mathrm{mg} / \mathrm{ml}$ ) of the aqueous extracts of Elaeis guineensis Jacq flower provoked the polymerization of $\mathrm{HbS}$ molecules apparently disclosing the capacity of the plant extract to perform with the hypoxemic mediator $\left(\mathrm{Na}_{2} \mathrm{~S}_{2} \mathrm{O}_{5}\right)$ synergistically at those concentrations, thereby enhancing hasty velocity of polymerization of $\mathrm{HbS}$ molecules in comparison with the control assay (Table 2). However, in the presence of $80 \mathrm{mg} / \mathrm{ml}$ and $100 \mathrm{mg} / \mathrm{ml}$ of the aqueous extracts, a decreased gelation of the $\mathrm{HbS}$ erythrocytes was observed (Table 2), which is a clear demonstration that the aqueous extracts of Elaeis guineensis Jacq flower actually possesses anti-sickling potentials but perhaps was overwhelmed due to their low concentration in the first three experimental doses. This finding embraces significant importance en route a feasible nutritionally-based therapeutic management for sickle cell individuals. Over the years, the use of aboriginal plants and herbal formulation in the management and control of diseases has been a regular exercise [40, 41].

In terms of improvement in the $\mathrm{Fe}^{2+} / \mathrm{Fe}^{3+}$ ratio of sickle cell blood, in vitro effect of the aqueous extracts of Elaeis guineensis Jacq flower on the $\mathrm{Fe}^{2+} / \mathrm{Fe}^{3+}$ ratio was observed and it can be seen that the extracts (Table 3) dose dependently improved the ratio. $\mathrm{Fe}^{2+} / \mathrm{Fe}^{3+}$ ratio is a measure of the oxygen affinity of the erythrocytes. Under hypoxic condition, this ratio decreases resulting in sickle cell crises. Prognostically, this can be used to monitor the prognosis of the treatment as well as the complications of the syndrome. Elsewhere, Nwaoguikpe et al. [42] reported the capacity of $T$. occidentalis, $C$. lonatus and $C$. sativus 
extracts to improve $\mathrm{Fe}^{2+} / \mathrm{Fe}^{3+}$ of $\mathrm{HbSS}$ blood ratio in vitro.

\section{Conclusions}

From this experimental study, it is concluded that the aqueous extracts of $E$. guineensis flowers exhibited high level potency in inhibiting sickle cell hemoglobin polymerization at increased concentration, improvement in $\mathrm{Fe}^{2+} / \mathrm{Fe}^{3+}$ ratio as well as maintaining erythrocyte membrane integrity, and providing the sickle cell disease patients with adequate nutrients and phytochemicals for a stable healthy status.

\section{Acknowledgements}

The authors are grateful to the ethics Committee of University of Port Harcourt for permitting the use of the HBS blood samples and the hematology department of University of Port Harcourt Teaching Hospital, Nigeria, for the provision of HbSS blood samples.

\section{Conflict of Interest Statement}

The authors report no conflict of interest.

\section{REFERENCES}

[1] Kutlar, A. Sickle cell disease: A multigenic perspective of a single gene disorder. Med. Princ. Pract. 2005; 14: 15-19.

[2] Bianchi, N., Zuccato, C., Lampronti, I, Borgatti, M., Gambari, R. Fetal hemoglobin inducers from the natural world: A novel approach for identification of drugs for the treatment of $\beta$-thalassemia and sickle-cell anemia. eCAM. 2009; 6 (2), 141-151.

[3] Xu, X., Lockamy, V.L., Chen, K., Zhi, H., Shields, H. Effects of iron nitrosylation on sickle cell hemoglobin solubility. Journal of Biological Chemistry, 2002; 277: 36787-36792.

[4] Xu, A. S. L., Labotka, R. J., London, R.E. Acetylation of human hemoglobin by methyl acetylphosphate: Evidence of broad regio-selectivity revealed by NMR studies. J. Biol Chem. 1999; 274: 26629-26632.

[5] Abdulmalik, O., Safo, M. K., Chen, Q., Yang, J., Brugnara, C. 5-hydroxymethyl-2-furfural modifies intracellularsickle haemoglobin and inhibits sickling red blood cells. British Journal of Haematology, 2005; 128 (4), 552-561.

[6] Billings, F. T.Treatment of sickle cell anemia with bone marrow transplantation-pros and cons. Trans. Am.Clin.Climatol.Assoc. 1990; 101, 8-20.

[7] Walters, M. C., Storband, R., Patience, M.. Impact of bone marrow transplantation for symptomatic sickle cell disease: an interim report. Blood. 2000; 95, 1918-1924.

[8] Fathallah, H., Atweh, G. F. DNA hypomethylation therapy for hemoglobin disorders: molecular mechanisms and clinical applications. Blood Rev. 2006; 20, 227-234.

[9] Okpuzor, J., Adebesin, O., Ogbunugafor, H., Amadi, I. The potential of medicinal plants in sickle cell disease control: A review. Inter. J. Biomed. Health Sci. 2008; 4 (2), 47-55.

[10] Imaga, N. O. A., Gbenle, G. O., Okochi, V.I., Adenekan, S. O., Edeoghon, S.O., Kehinde, M.O., Bamiro, S.B., Ajiboye, A., Obinna, A.. Antisickling and toxicological profiles of leaf and stem of Parquetina nigrescens L. J. Med. Plants Res. 2010; 4 (P8), 639-643.

[11] Chikezie, P. C. Sodium metabisulphite induced polymerization of sickle cell haemoglobin $(\mathrm{HbS})$ incubated in extracts of three medicinal plants (Anacardium occidentale, Psidium guajava and Terminalia catappa). Pharmaco. Mag. 2011; 7 (26): 126-132.

[12] Chikezie, P. C. and Uwakwe, A. A. Membrane stability of sickle erythrocytes incubated in three medicinal plants: Anacardium occidentale, Psidium guajava and Terminalia catappa. Pharmaco. Mag. 2011; 7 (26), 121-125.

[13] Bulson, A. M., Kawchalk, D.A., Schall, J.T., Ohene-Frempong, K., Stallings, V. A and Zemel, B. S. Low vitamin D status in children with sickle cell disease. Journal Pediatri, 2004; 145 (5):622-627.

[14] Ibegbulem C. O., Chikezie P. C. Serum lipid profile of rats (Rattus norvegicus) fed with palm oil and palm kernel oil-containing diets. Asian J. Biochem. 2012; 7(1): 46-53.

[15] Tsakiris, S., Giannoulia-Karantana, A., Simintzi, I., Schulpis, K. H. The effect of aspartame metabolites on human erythrocyte membrane acetylcholinesterase activity. Pharmacol. Res. 2005; 53: 1-5.

[16] Pennings, H. J., Borm, P.J. A., Evelo, C. T. A., Wouters, E. F. $M$. Changes in levels of catalase and glutathione in erythrocytes of patients with stable asthma, treated with beclomethasonedipropionate. Euro.Respir. J. 1999; 13, 1260- 1266

[17] Galbraith, D. A., Watts, D. C. Changes in some cytoplasmic enzymes from red cells fractionated into age groups by centrifugation in Ficoll ${ }^{\mathrm{TM}} /$ Triosil $^{\mathrm{TM}}$ gradients: Comparison of normal human and patients with Duchenne musculardystrophy. Biochem. J. 1980; 191: 63-70.

[18] Kamber, K., Poyiagi, A., Delikonstantinos, G. Modifications in the activities of membrane-bound enzymes during in vivo ageing of human and rabbit erythrocytes. Comp Biochem. Physiol. B. 1984; 77B: 95-99.

[19] Iwu, M. N., Igboko, A. O., Onwubiko, H., Ndu, U. E. Effect of Cajanuscajan on gelation and oxygen affinity of sickle cell hemoglobin. J. Ethnopharmacol. 1988; 20, 99-104.

[20] Chikezie, P. C., Chikezie, C. M., Amaragbulem, P. I. Effect of antimalarial drugs on polymerization of sickle cell hemoglobin (HbS). Turk. J. Biochem. 2010; 35 (1), 41-44.

[21] Dewey, M. J., Brown, J. L., Nallaseth, F. S. Genetic difference in red cell osmotic fragility: analysis in allophenic mice. Blood, 1982; 59, 986-9.

[22] Davidson J, Henry JB. Determination of Hemoglobin and 
Methemoglobin. Clinical Diagnostics by Laboratory methods. Todd Sanford, W.B. Saunders, Philadelphia. 1974; 112,1380

[23] Raj, A., Rifkin, S. A., Andersen, E., and van Oudenaarden, A. Variability in gene expression underlies incomplete penetrance. Nature, 2010; 463(7283), 913-918.

[24] Elekwa, I., Monanu, M. O. and Anosike, E. O. Effects of aqueous extracts of Zanthoxylum macrophylla roots on membrane stability of human erythrocytes of different genotypes. Nigerian Society for Experimental Biology. 2005

[25] Kang, S. S. and Benjamin, G. Homoserine inhibition of in vitro sickling of erythrocytes. Expt. Mol. Pathol. 1975; 22:220-225.

[26] Rice-Evans, C., Omorphos, S.C., Baysal, E. Sickle cells membranes and oxidative damage. Biochemical Journal, $1986 ; 237,265-9$.

[27] Tamer, L., Polat, G., Yücebilgiç, G., Güvenç, B., Başlamışl, F. The levels of sera malondialdehyde, erythrocyte membrane $\mathrm{Na}+-\mathrm{K}+/ \mathrm{Mg}++$ and $\mathrm{Ca}++/ \mathrm{Mg}++$ adenosine 5' triphosphatase in patients with sickle cell anemia. Turk $J$ Haematol., 2000; 17, 23-6.

[28] van Kuijk, F. J., Sevanian, A., Handelman, G. J., Dratz, E. A. A new role for phospholipase A2: Protection of membranes from lipid peroxidation damage. TIBS, 1987; 12, 31-4.

[29] Bharani, A., Ganguly, A., Bhargava, K. D. Salutary effect of Terminalia arjuna in patients with severe refractory heart failure. International Journal of Cardiology, 1995; 49, 191-9.

[30] Middleton, E., Kandaswami, C., Theoharides, T. C. The effects of plant flavonoids on mammalian cells: Implications for inflammation, heart disease, and cancer. Pharmacol Rev, $2000 ; 52,673-751$.

[31] Rice-Evans, C. Flavonoid antioxidants. Curr Med Chem., 2001; 8, 797-807.

[32] Benavente-García, O., Castillo, J, Marin, F. R., Ortuño, A., Del Río, J. A. Uses and properties of Citrus flavonoids. Journal of Agriculture Food and Chemistry, 1997; 45, 4505-15.
[33] Okwu, D. E. Nigerian medicinal plants I. Med Aromat Plant Sci Biotechnol., 2007; 1, 90-6.

[34] Miliauskas, G., Venskutonis, P. R., van Beek, T. A. Screening of radical scavenging activity of some medicinal and aromatic plant extracts. Food Chem., 2004; 85, 231-7.

[35] Kumar, G. S., Jayaveera, K. N., Ashok, C. K., Bharathi, T., Umachigi, S. P., Vrushabendra, S. Evaluation of antioxidant and antiacne properties of terpenoidal fraction of Hemidesmus indicus (Indian sarsaparilla). Int $J$ Aesth Antiaging Med., 2008; 1, 1-8.

[36] Awe, E. O., Makinde, J. M., Adeloye, O. A., Banjoko, S. O. Membrane stabilizing activity of Russelia equisetiformis, Schlecht and Chan. Journal of Natural Products, 2009; 2, 3-9.

[37] David, S. Studies force new view on biology of flavonoids. Bio Med. 2007; 541, 737-87.

[38] Chandran, P. G., Balaji, S. Phytochemical investigation and Pharmacological studies of the flowers of Pithecellobium dulce. Ethnobotanical Leaf, 2008; 12, 245-53.

[39] Elekwa, I., Monanu, M. O. and Anosike, E. O. Effects of aqueous extracts of Garcinia kola seeds on membrane stability of HbAA, HbAS and HbSS human erythrocytes. Global J. of Medical Sciences, 2003; 2 (2), 97-101.

[40] Iwu, M.M. Handbook of African Medicinal plants. CRC Press, London, 1993; 1-17.

[41] Thompson, L. U. Potential health benefits and problems associated with anti-nutrients in foods. Food Research International, 1993; 26, 131-149.

[42] Nwaoguikpe, R. N., Ujowundu, C .O and Okwu, G. N. The Antisickling Potentials of Four Curcubits (T. Occidentalis, C. Maxima; C. Sativus and C. Lonatus). Scholars Journal of Applied Medical Sciences, 2013; 1 (3), 191-198.

[43] Ekwenye, U. N., Ijeomah, C. A. Antimicrobial effects of palm kernel oil and palm oil. KMITL Sci J. 2005; 5, 502-505.

[44] Nwaichi, E. O. Osuoha, J. O. and Monanu, M. O. Nutraceutical Potential of Tetracarpidium conophorum and Buccholzia coriacea in Diet-induced Hyperlipidemia. Journal of Chemical Health Risks, 2017; 7 (3), 157-170. 